\title{
THE RELATION OF FEDERAL AND STATE SECURITIES LAWS
}

\author{
RUsserI A. SMITH*
}

State "Blue Sky" laws antedated by more than twenty years the Securities Act of 1933 and the Securities Exchange Act of 1934. At the time of the passage of those Acts every state but one had on its statute books legislation relating to the sale of securities. The entrance of the federal government upon the field did not result in a repeal of any of the state laws. Such laws remain extant and their administration has, if anything, received renewed vitality from the prevailing public interest in the regulation of transactions in securities. It is pertinent to examine briefly into the scope of the federal and state laws, to determine the extent to which they are concurrently applicable, and to ascertain the need, if any, for correlation of the regulatory functions of the federal and state governments.

State "Blue Sky" laws differ widely, evincing a lack of uniformity both in objective and in means for attaining similar objectives. It is apparently the policy of some states, as disclosed by their statutes, the administration thereof, or both, not only to prevent fraud by requiring factual disclosures and establishing penalties for misrepresentation and deceit, but also to prevent the sale of certain securities (on the theory, perhaps, that they are unsound or per se fraudulent) or the sale of any securities on terms not considered fair. ${ }^{1}$ Other states, less paternalistic in this respect,

- A.B., 1929, Grinnell College; J. D., 1934, University of Michigan. Member of the New York Bar. Associate, Cravath, de Gersdorff, Swaine \& Wood, New York City, since September, 1934. Author of State "Blue-Sky" Laws and the Federal Securities Acts (1936) 34 Mircr. L. REv. Ir35.

${ }^{1}$ The following provisions, selected at random, are illustrative:

Section 9887 of the Alabama Securities Act, ALA. CODE (Michie, 1928) c. 335, provides that the commission shall refuse to qualify securities upon finding, inter alia,

"(a) That the sale of such securities would work a fraud, deception or imposition upon the purchasers thereof, or that the proposed disposal of such securities is on unfair terms; or

"(b) That the articles of incorporation or association, declaration or trust, charter, constitution, bylaws, or other organization papers of the issuer are unfair, unjust, inequitable, illegal or oppressive; or

"(c) That the issuers or guarantors of such securities are insolvent, or are in failing circumstances, or are not trustworthy; or

"(d) That the issuer's plan of business is unfair, inequitable, dishonest, or fraudulent; or . .

"(f) That the reasonable value of any property or assets of the issuer for which the issuer has issued or proposes to issue securities is less than the par or face value, or the issue price, as the case may be, of all of the securities of the issuer so issued or to be issued in payment therefor; or ...

"(h) That the sale of such securities is a mere scheme of either the issuer or the applicant to dispose of worthless securities of no real intrinsic value, at the expense of the purchasers of said securities; ...."

Section 8 of the Florida Uniform Sale of Securities Act, Fla. Laws 1931, c. 14899, requires a finding 
seek only to prevent fraud, leaving it to the individual purchaser to determine, unhampered by misrepresentation, the wisdom of his purchase. ${ }^{2}$ Irrespective of their underlying policies, the various state laws may be roughly classified with respect to their objective requirements as follows: ${ }^{3}$

( $x$ ) the "fraud" type of law, which does not require either the "qualification" (i.e., registration or approval) of securities or the "licensing" of dealers in securities but, in general, merely provides penalties for fraud and authorizes injunctive proceedings to prevent fraud;

(2) the "licensing" type of law, which, in general, requires dealers in securities to be licensed but does not require that securities be qualified;

(3) the "inspection" type of law which, in general, requires that securities be qualified but does not require that dealers be licensed; and

(4) the "licensing and inspection" type of law, which requires both that securities be qualified and that dealers be licensed and which is the most common type of law.

The duties of administration of the laws are variously reposed with the attorney general's office (customary in the case of a fraud law), some pre-existing body such as the corporation or public utilities commission, or, more frequently, a commission or an office created especially for the purpose. The administrative bodies are, as a rule, clothed with broad discretionary powers, in some cases unguided save by the vaguest standards.

\section{Coincidence of Federal and State Laws}

If not inevitable, it is at least to be expected that to some extent the state and federal securities laws should be concurrently applicable. The federal laws purport primarily to be an exercise of the commerce power, and hence to be regulations of interstate transactions in securities. But every such transaction is, of course, only a sequence of intrastate acts having incidence in at least two states, and over all acts done within a state, whether or not they are related to acts done beyond its boundaries, the state may logically (in the absence of some constitutional barrier) assert jurisdiction. Thus, an offer to sell securities, made by dealer $\mathrm{A}$ in State $\mathrm{X}$ through

by the Commission, prior to registration of securities, that, among other things, "the enterprise or business of the issuer is not based upon unsound business principles."

Section 27 of the New Hampshire Blue Sky Law, N. H. PuB. LAws (1926) c. 284, provides as follows:

"If the commissioner is of the opinion that such securities are of such a character that there is a serious financial danger to the purchaser in buying them, or that the circulars and advertisements do not disclose pertinent facts sufficient to enable intending purchasers to form a correct judgment of the nature and value of the securities, he may prohibit the dealer from selling or offering the securities, or any of them, or in any way advertising them."

Section 8 of the Vermont Securities Act, VT. PuB. LAws (1933) c. 274, provides that the commissioner shail register securities upon application if he finds "that the sale of the security... would not be fraudulent and would not tend to work a fraud upon the purchaser, and that the enterprise or business of the issuer is not based upon unsound business principles, and that in his judgment the enterprise promises a fair return to the purchaser of its securities."

${ }^{2}$ Among such states are Delaware, Maryland, New Jersey, New York and Illinois. The first four of such states have the "fraud" type of law, whereas Illinois has the "licensing and inspection" type (see the classification immediately following in the text).

'See Smith, State 'Blue-Sky' Laws and the Federal Securities Acts (1936) 34 Mrch. L. Rev. 1135, I137. 
the mails to customer B in State $Y$, and accepted by B through the mails, resulting in delivery and payment in X-clearly an "interstate" transaction-consists, in fact, of certain acts in State $X$ and certain acts in State $Y$. In State $X$ there occurs at least a partial transmission of the offer, a partial transmission of the acceptance, and the delivery of and payment for the securities and, possibly, depending on the terms of the offer, the making of the contract. In State $Y$ there occurs at least a partial transmission of the offer and a partial transmission of the acceptance, and, possibly, again depending on the terms of the offer, the making of the contract. If States $X$ and $Y$ have the "licensing and inspection" type of securities law, and if such law is intended to apply to such a transaction, under the facts stated, and waiving constitutional questions, A must be licensed as a dealer, and the securities must be qualified (unless exempt) under the laws both of $X$ and $Y$, failing which the contract may be voidable at B's option either under the laws of $X$ or of $Y$.

It has elsewhere been shown that under decisions of the Supreme Court, while the question is, unfortunately, not entirely free of doubt, the interstate character of such a transaction probably does not in and of itself preclude such an application of state laws. ${ }^{4}$ It has also been suggested that while Congress could, either by express declaration or by implication through substantial occupancy of the field, supervene and withdraw from the states such jurisdiction as they may have over interstate transactions in securities, it has not done so in either of the federal securities acts, which, on the contrary, expressly preserve to the state securities commissions their pre-existing jurisdiction. ${ }^{5}$ State laws may thus, depending probably only upon their scope, ${ }^{6}$ be applicable to interstate transactions.

On the other hand, the federal laws are not restricted (except by constitutional barriers, if any) to transactions clearly interstate in character. The Securities Act of I933 applies to sales of securities by "any means or instruments of transportation or

'Smith, supran note 3, at rI 45 et seq. The leading cases there discussed are Hall v. Geiger-Jones Co. 242 U. S. 539 (I9I7); Caldwell v. Sioux Falls Stock Yards Co., 242 U. S. 559 (I9I7); and Merrick v. N. W. Halsey \& Co., 242 U. S. 568 (I9I7).

'See Smith, supra note 3 at Ix58. Section 18 of the Securities Act of 1933, 48 STAT. 74, I5 U. S. C., c. $2 A$, provides:

"State control of securities.-Nothing in this title shall affect the jurisdiction of the securities commission (or any agency or office performing like functions) of any State or Territory of the United States, or the District of Columbia, over any security or any person."

Section 28 of the Securities Exchange Act of 1934, 49 STAT. 88I, 15 U. S. C., c. 2B, provides:

"The rights and remedies provided by this title shall be in addition to any and all other rights and remedies that may exist at law or in equity; but no person permitted to maintain a suit for damages under the provisions of this title shall recover, through satisfaction of judgment in one or more actions, a total amount in excess of his actual damages on account of the act complained of. Nothing in this tutle shall affect the jurisdiction of the securities commission (or any agency or officer performing like functions) of any State over any security or any person insofar as it does not conflict with the provisions

"Many of the state laws apply only to "sales" made "in this state." Customarily, "sale" is defined very of this title or the rules and regulations thereunder."

broadly to include offers, solicitations of offers and all attempts to sell. It is a question of statutory construction of such definition of "sale" whether an offer originating in a foreign state and made through the mails or some other interstate instrumentality constitutes a sale within the state in question. Except for such broad definitions, an offeror in one state could successfully avoid the application of the laws of other states by providing that contracts should not be deemed made until communication of acceptances. 
communication in interstate commerce or of the mails." "Whether or not a sale of securities by $A$ in State $X$ to $B$ in State $X$, concluded by telephone, is a transaction within the Act because the telephone is, potentially, a means of communication in interstate commerce, in any event a sale completed between $A$ and $B$ by mail is expressly within the Act. The intended scope of the Act is further indicated by the fact that there is included an express exemption of intrastate transactions of very limited application. Securities are exempt from registration requirements under this provision only if the entire offering is confined to the state of domicile of the issuer. ${ }^{8}$ In other words, if $\mathrm{A}$ in State $\mathrm{X}$ offers unregistered securities to $\mathrm{B}$ in State $\mathrm{X}$, when neither the security nor the transaction is exempt, he violates the Securities Act of I933 if any part of the offering is made in another state or if the issuer is a corporation of some other state.

Similar observations may be made concerning the Securities Exchange Act of 1934. Assuming that a "national securities exchange," within the meaning of the Act, is an instrumentality of interstate commerce, specific subjects covered by the Act are not clearly interstate in character. Thus, to mention a few instances, the Act provides for margin requirements in connection with loans on any security (other than an exempted security) registered on a national securities exchange, whether or not the loan is arranged for in interstate commerce, and whether or not the purpose of the loan is to effect a purchase of the security on the exchange. ${ }^{9}$ Members of a national securities exchange (and persons who transact a business in securities through the medium of a member) are subjected to restrictions on borrowing applicable to all their transactions, even those entirely dissociated from the exchange. ${ }^{10}$ The facts ( $I$ ) that a person is a member of a national securities exchange (or transacts a business in securities through the medium of a member) and (2) that he engages in a transaction relating to a security (other than an exempted security) registered on a national securities exchange are made the basis for subjecting him to certain restrictions (viz., margin requirements, prohibitions against manipulation, regulation of the solicitation of proxies) even though such transaction is purely local and not consummated on the exchange. ${ }^{11}$

${ }^{7}$ Securities Act, $\$ 55,12,17$.

"Thus, $\S_{3}(\mathrm{a})(\mathrm{II})$ exempts "any security which is a part of an issue sold only to persons resident within a single State or Territory, where the issuer of such security is a person resident within, or, if a corporation, incorporated by and doing business within, such State or Territory." Under this provision it may be that even if an entire issue is sold in the state of incorporation of the issuer, the exemption docs not apply if the issuer is not "doing business"-i.e., actually conducting its operations-in such state. For a discussion of 53 (a)(II), see Throop and Lane, Some Problems of Exemption under the Securities Act of 1933, in Part 1 of this symposium (Jan. 1937) 4 Law and Contemporary Problems, 89, 107 et seg.

- Section 7(d) provides: "It shall be unlawful for any person not subject to subsection (c) to extend or maintain credit or to arrange for the extension or maintenance of credit for the purpose of purchasing or carrying any security registered on a national securities exchange, in contravention of such rules and regulations as the Federal Reserve Board shall prescribe to prevent the excessive use of credit for the purchasing or carrying of or trading in securities in circumvention of the other provisions of this section. ..."

Securities Exchange Act, $\$ 8$.

${ }^{11} I d ., 557,9,14$. 
It thus appears that persons dealing in securities may find themselves apparently subject both to state and federal regulation. The significance of this fact, so far as the federal requirements are concerned, has been the subject of extended discussion and is comparatively well known. The problems presented by the state laws are not so well known, nor has the value of or necessity for concurrent state regulation been adequately appraised. A brief survey of certain of the problems which may arise under the state laws in connection with transactions which, with one exception, ordinarily require registration under the Securities Act of 1933 will indicate the need for such an appraisal. The purpose will be, for the most part, rather to state the problems than to answer them. It is assumed for the purpose of this discussion that there exists no immunity from the state laws by virtue of the interstate character, if any, of such transactions.

\section{Particular "Blue Sky" Problems}

\section{(1) Transactions by Issuers-Offers to Stockholders, Mergers, etc.}

Suppose X, a Delaware corporation, having its principal place of business in New York, and having numerous stockholders scattered throughout the country, desires to make an offer of a new class of preferred stock (convertible into common stock) to its existing preferred stockholders, in exchange, share for share, for outstanding preferred stock, and to make an offer to its common stockholders of any of such stock not taken by the preferred stockholders, the offers to be underwritten by certain bankers who will receive, as compensation for their commitments, a stipulated sum for each share of stock offered, plus an additional sum for each share of stock which is purchased by them. Preferred stockholders desiring to accept the offer will be required to deposit their shares with a specified depositary in New York or San Francisco. The outstanding common stock of the Company is listed on the New York Stock Exçhange. The "Blue Sky" questions which arise are several.

Since the offering is to be made in New York, as to New York stockholders, the first state securities law to be examined is the New York "Martin Act."12 In its affirmative requirements that Act, which is a modified fraud law, applies only to "dealers" in securities, as defined therein. Whether the Company, in making the proposed offer, and the New York depositary, in acting as an agency in facilitating acceptances of such offer, will be dealers in securities depends upon ( $I$ ) whether they will be engaged "in the business of trading in securities" in such manner that any of such securities are (2) "sold or offered for sale to the public" in New York.18

${ }^{23}$ N. Y. Cons. Laws (Cahill, 1930) c. 21, art. 23-A.

13 Section 359-e of the Act, supra note 12, provides that "no dealer shall sell or offer for sale to the public within this State, as principal, broker, or agent any securities issued or to be issued" unless certain statements and notices are filed as therein required. This section defines "dealer" to "include every person. partnership, corporation, company, trust or association, except a domestic municipal corporation, who engages dircetiy or through an agent in the business of trading in securities in such manner that as part of such business any of such securities are sold or offered for sale to the public in this State ...." but provides that "a sale or offer of sale to the public shall not include . . . any sale or offer of sale to any person engaged in the business of acquiring securities for the purpose of resale; any sale or offer of sale to a 
If the Company and the depositary will be dealers within such definition, certain statements and notices must be filed under the Act.

It must next be decided whether any affirmative action must be taken by the Company (or by the New York or California depositaries) in compliance with the "Blue Sky" laws of other states in which stockholders reside. If no action need be taken by the Company under a particular state law, a fortiori no action need be taken by either of the depositaries. Whether, in any case, action must be taken by a bank acting as a depositary under such or similar circumstances is a question depending upon the scope of the law in question and upon the particular function of the depositary and the manner of its exercise. ${ }^{14}$

Except for possible exemption provisions, compliance with the laws of such other states may, depending upon their scope, require, in some cases, that the Company register as a dealer in securities, in others that the new preferred stock be qualified for sale by the filing of more or less extensive data concerning the Company, in still others that both procedures be followed. ${ }^{15}$ Either procedure will probably involve

banker, to a dealer, or to a corporation, or to any syndicate or group formed for the specific purpose of acquiring such securities for resale to the public directly or through other syndicates or groups, or any sale or offer of sale upon the floor of any exchange to a broker in securities."

An argument may, of course, be made that an issuer in making an offering of securities of a single issue to such stockholders as it may have in New York is neither engaged "in the business of trading in securities" nor offering its securities "to the public in this State." The former phrase is, however, one easily subject to broad construction by anyone desirous of giving fullest effect to the law, and the Department of Law, in promulgating its instructions governing the filing of the "Original Dealer's Statement" states affirmatively that "corporations desiring to sell their own securities direct to the public must also qualify as a dealer by filing Statements described herein." Whether such instruction is intended to cover all direct offerings by an issuer or only those of a continuous and recurring nature (which could more easily be said to constitute the "business of trading in securities") is not apparent. That an offering to stockholders may be a "public offering" (depending entirely on the number of stockholders involved) is clear. See the collection of cases in Commerce Clenring House, Stocks and Bonds Law Service, Vol. III., par. 2203.03.

"The question would be whether the depositary would be "selling" securities. Definitions of "scll," under the various state laws, are customarily very broad. Any attempt to sell, solicitation of a sale or of an offer to buy, and "any act by which a sale is made" usually constitute sales within such definitions (cf. the definition contained in the Illinois Securities Law, InI. REv. Stat. (I935) c. 32, par. 255, \$2(4)). If a depositary merely acts passively as a conduit for depositing stockholders, and has no part in the actual making of the offer, it is obviously not attempting to sell, though it conceivably could be said that the act of receiving deposits, and issuing some evidence thereof, is an "act by which a sale is made." Such reasoning, however, would bring not only depositaries, but also transfer agents, registrars and all other agencies designed to facilitate the issuarice of securities within the "Blue Sky" laws, and, so far as the writer knows, no state commission has attempted to assert jurisdiction over such agencies. If a depositary has some connection with the making of the offer (if, for example, it sends out letters to the stockholders apprising them of the offer and advising that deposits may be made with it by those desiring to accept), there is perhaps a more serious question about the applicability of the state laws.

${ }^{15}$ The applicability of many of the statutes will depend upon (1) whether the offer made through the interstate mails will constitute a sale "in" the state in question, despite the fact that (if such is the case) the acceptance completing the contract occurs in the state of residence of the Company, and (2) whether the Company in making such offer through the interstate mails will be engaging "in the business" of dealing in securities in the state in question (a question similar to that discussed in connection with the New York Act in note 13, stupra). Clearly, an offer communicated in the state, even though not originating therein, is, strictly speaking, an offer in the state. It may be contended, however, that offers of this type, where the offeror is beyond the jurisdiction of the state, are not contemplated by the statute. 
subjection, limited or unlimited, ${ }^{16}$ by the Company to service of process and may make it necessary ${ }^{17}$ for the Company to qualify as a foreign corporation under the general corporation laws of one or more states.

A considerable number of the state laws exempt company offers provided they are made exclusively to stockholders and provided no commissions or fees are paid in connection with such offers. ${ }^{18}$ Does the underwriting involved in the hypothetical case destroy/such exemption, in that it involves a contingent sale to others than stockholders, or in that the underwriters' commissions, to be based in part on stock taken pursuant to the offer to stockholders, will be commissions or fees paid "in connection with" the offer to the stockholders? ${ }^{19}$ In many states the new securities will be exempt from qualification requirements if they are "senior" to the listed common stock of the Company. ${ }^{20}$ At first blush it would seem obvious that such

\footnotetext{
${ }^{20}$ In some states subjection to service will be for the purpose of service in all actions or proceedings arising in the state, whereas in others subjection will only be for the purpose of service in actions and proceedings arising out of security transactions.

${ }^{27}$ Necessary, that is, under the "Blue Sky" laws, as a prescribed condition precedent to obtaining 2 dealer's license or to qualification of the securities. Under ordinary principles, qualification as a foreign corporation would not be required as a condition to engaging in business in interstate commerce.

${ }^{13}$ Thus, $\$ 5$ of the Illinois Securities Law, supra note 14 , exempts sales of "(2) Securities of a corporation when sold or distributed by it among its stockholders without the payment of any commission or expenses to agents, solicitors or brokers, and without incurring any liability for any expenses whatsoever, in connection with the distribution thereof."

10 In 2 discussion of a similar provision $\left(\$_{3}(a)(9)\right)$ of the Securities Act of 1933 in Throop and Lane, Some Problems of Exemption under the Securities Act of 1933, Part I of this symposium, supra note 8, at p. 96 ff.), it has been contended that "the exemption is available only to securities constituting part of an issue which, as a whole, is exchanged in conformity with the requirements - of : section." As applied to the hypothetical case under discussion, the applicability of the exemption would, on this basis, depend upon the suecess of the offering (i.e., upon whether any securities remain for purchase by the underwriters). If this interpretation is correct, an issuer under such circumstances must obviously register the offering at the outset.
}

An important difference between said $\$ 3(a)(o)$ of the Federal Act and the equivalent provision of the state laws is that the exemption given by the former is, presumably, retained by the security, since the security itself is'exempt, whereas the state provisions as a rule only exempt the particular transaction. Such difference may be sufficient to justify the more liberal interpretation that the state provisions will exempt the offering to the stockholders in the hypothetical case as being one complete offering, with no contemporancous offering to others than stockholders, the later public offering, if any, by the underwriters of 2ny securities not taken by the stockholders being a second distinct transaction not exempt under such provision. The public interest will be amply served by the qualification of any securities sold to the stockholders which may become necessary in any subsequent dealing therein by persons subject to the state laws, and by the qualification effected, to the extent necessary, in connection with such offering as may be made by the underwriters.

${ }^{20}$ This is true in Alabama, Colorado, Florida, Georgia, Idaho, Indiana, Iowa, Kansas, Kentucky, Minnesota, Missouri, Montana, Nebraska, North Dakota, Ohio, Oregon, South Carolina, South Dakota, Texas, Utah and Vermont.

Some of the statutes specify no exchanges, but permit the commission to designate any exchanges whose listing requirements meet certain standards. Others specify certain exchanges and give a discretionary power to the commission to add other exchanges. A typical provision of the latter type is $\$ 3$ (4) of the Ohio Act, Ohio Gen. Code (Page, 1932 Supp.) \$8624-3, as amended, Ohio Laws 1935, p. 265, which exempts

"Any security, whether a preliminary or final sccurity, which, at the time of sale within this state, is listed on the Cincinnati stock exchange, the Cleveland stock exchange, the New York stock exchange or the New York curb market, or any other stock exchange which may be approved of by the division as having listing requirements substantially equivalent to those of any one of the exchanges hereinabove specified, also any security senior to any security so listed; provided this exemption shall apply only so 
exemption provisions will be applicable, for a stock preferred as to dividends is clearly senior to a common stock. This conclusion, however, overlooks the conversion privilege attaching to the new preferred stock. Does that privilege mean that in reality two securities (preferred and common stock) are to be offered? If so, the stock exchange exemption will be of little avail. ${ }^{21}$ These and other questions will beset a company contemplating such an offer.

"Blue Sky" problems in connection with mergers and consolidations are likewise pressing. If a particular merger or consolidation plan is being promulgated, as is most likely, by the managements of the respective constituent companies, it must first of all be decided whether the solicitation of proxies favoring the merger or consolidation, exercisable at the respective stockholders' meetings, is a solicitation of an offer to buy securities of the proposed resulting or new corporation into which outstanding securities will be converted, within the meaning of the very broad definitions of "sale" contained in most of the state laws. It must also be decided whether the subsequent issue of securities of the resulting or new corporation, upon the conversion into such securities of securities of the constituent companies, or the subsequent issue of certificates representing such new securities, upon surrender of old certificates, will involve a "sale." If a sale within the meaning of any of the state laws will be involved, it may be necessary (in the absence of any applicable exemption) to take action in compliance with such laws. It may, for example, conceivably be necessary for the constituent companies or their managements, and the new or resulting corporation, to register as dealers in securities and for the securities of such corporation to be qualified.

The solicitation of proxies, the issue of new securities and the subsequent distribution of certificates representing such securities, as aforesaid, pursuant to a statutory merger, are not "sales" in any ordinary sense. The Securities and Exchange Commission has recognized this in ruling that such transactions do not require

\footnotetext{
long as such security shall be and remain listed, pursuant to official action of such exchange, and not under suspension, and so long as such exchange remains approved under the provisions of this Act."

${ }^{n}$ The laws of some of the states expressly resolve all doubt on this question by providing that a sale of a convertible security shall not be deemed to be a sale of the security into which the former is convertible. Thus, $\$ 8581-c_{3}(3)$ of the Iowa Securities Law, Iown CODE (1935) c. 391-c, in defining "sale" provides, inter alia:

". . a privilege pertaining to a security giving the holder the privilege to convert such security into another security of the same issuer shall not be deemed a sale, or offer to sell, or option of sale of such other security within the meaning of this definition and such privilege shall not be construed as affecting the status of the security to which such privilege pertains with respect to exemption or registration under the provisions of this chapter. . .."

Other statutes accomplish the same result by specifying the giving of a conversion right as an exempt transaction. Section $4(6)$ of the Ohio Securities Act, supra note $20, \$ 8624-4(6)$, for example, exempts

"The giving of any conversion right, subscription right, warrant or option to purchase securities with, or on account of the purchase of, any security which is excmpt, or which is the subject matter of an exempt transaction, or which has been registered by description, registered by qualification, or which is the subject matter of a transaction which has been registered by description hercunder."

The laws of other states, however, leave the question unsettied and one must attempt to determine whether, from the definitions of "security" and of "sale" could be conjured up, in the case of convertible securities, a sale of two securities.
} 
registration of the new securities under the Securities Act of $1933 .{ }^{22}$ Analytically, the definitions of "sale" contained in most of the state laws would seem to require a similar conclusion. ${ }^{23}$ Yet some of the state laws containing such definitions proceed, inconsistently, to exempt from qualification requirements securities issued in connection with mergers and consolidations. ${ }^{24}$ If such transactions do not involve "sales" of securities, such an exemption would seem not to be necessary, for the existence of an exemption presupposes that, except for the exemption, the transaction exempted would be subject to the act. Moreover, it might well accord with the policy of a particular state to scrutinize mergers and consolidations, in the interest of the stockholders of the constituent corporations residing in such state, as well as transactions involving "sales" of securities in the ordinary sense.

The foregoing serve to illustrate the nature of the "Blue Sky" problems which confront corporations in connection with their direct offerings and related transactions. In any case where a corporation proposes to make an offering of securities (whether of warrants, rights, securities issued upon conversion or ordinary offerings) problems under the various state laws immediately arise. The only practical solution in many cases (where qualification proceedings and other action required by the various state laws, on the assumption they are applicable, would be physically impossible within any reasonable time schedule, if at all) is to take the position that the state laws, other than those of the state of origination of the transaction, are inapplicable because there will be no "offer" made, "sale" consummated or "business"

In the Rules for the Use of Form E-I (for the registration of securities issued in reorganizations) appears the following:

"Note. The Commission deems no sales to'stockholders of a corporation to be involved, within the meaning of the definition quoted in Rule 5(2) [the definition contained in the Securities Act of 1933] where, pursuant to statutory provisions or provisions contained in the certificate of incorporation, there is submitted to the vote of such stockholders 2 proposal for the transfer of assets of such corporation to another person in consideration of the issuance of securities of such other person, or a plan or agreement for 2 statutory merger or consolidation, provided the vote of a required favorable majority

(a) will operate, so far as the corporation the stockholders of which are voting is concerned, to authorize the transfer or to effectuate the merger or consolidation (except for the taking of action by the directors of the corporations involved and for compliance with such statutory provisions as the filing of such plan or agreement with the appropriate state authorities), and

(b) will bind all stockholders of such corporation, except to the extent that dissenting stockholders may, under statutory provisions or provisions contained in the certificate of incorporation, be entitled to receive the appraised value of their holdings."

2 A solicitation, by the management of a corporation, of proxies to vote on a proposed merger or consolidation involving the corporation obviously cannot be an offer of securities, either by the solicitors or by the corporation, because the securities proposed to be issued will not be securities of such corporation but will be securities of the new or surviving corporation and because, in any event, it is the very action of the stockholders in voting upon the merger or consolidation, plus other actions as required by the governing statute or statutes, which will bring into being the new securities. A solicitation, by the management of the proposed surviving corporation of proxies, to vote on a proposed merger is likewise not an offer for the second of such reasons. Upon the favorable vote of the stockholders and the taking of such other action as may be required by law (viz., the execution, filing and recording of the agreement of merger), the old securities are at once converted into the new, and the subsequent issue of new certificates in exchange for outstanding certificates cannot be a "sale" of securities, for the securities are already outstanding.

$\boldsymbol{s}$ This is true in Alabama, Florida, Indiana, Iowa, Kansas, Kentucky, Michigan, North Carolina, Oklahoma, South Carolina, Texas, Utah and Vermont. 
transacted within such states. That the question is not free from doubt creates a most unsatisfactory situation.

\section{(2) Problems Involved in Underwritings}

A straight underwriting involves, of course, a sale by the issuer to the underwriters and a resale by the underwriters directly to the public or to dealers who resell to the public. Sales by issuers to underwriters ordinarily do not raise manifold "Blue Sky" problems, since such sales are usually either exempt or at most require the issuer to take affirmative "Blue Sky" action in but one or two states. ${ }^{25}$

Sales by underwriters to local dealers raise problems in about a dozen states whose laws do not exempt such sales. ${ }^{26}$ Such laws, assuming that there will be involved an "offer" made, a "sale" consummated, or "business" transacted within such states, may make desirable either an allotment of all orders received from dealers in such states to one or more of the underwritess who are registered as dealers therein (which involves difficult practical problems) or else, lacking any such underwriters, the exclusion of such dealers from participation in the offering. Public offerings by the underwriters (subject to the question whether, if the offering is of an interstate character, a "local" offering is involved, within the meaning of the state laws) and, in any event, a public offering by the members of the dealer selling group necessitate qualifying the securities, except in so far as they may be exempt, under the laws of all states included in the offering which have either the "inspection" or the "licensing and inspection" type of statute.

Problems also arise in connection with advertising. Underwriters customarily publish, contemporaneously with a public offering, either a newspaper announcement of the offering or the more elaborate "newspaper prospectus," both as permitted by regulations of the Securities and Exchange Commission. While such advertisements do not constitute offers under the Securities Act of 1933 , it is conceivable that they are encompassed by the broad definitions of "offer" contained in many of the state laws, and such is the view of certain of the state "Blue Sky" officials. ${ }^{27}$ Accordingly, it is customary (whether or not necessary as a matter of law) not to publish any such advertisement in any state whose law would require qualification of the issue prior to a sale in such state unless the issue has been duly qualified. It is also customary to restrict the appearance of underwriters' names in any such advertisement, published in a state whose law requires dealers to be licensed, to those underwriters who are licensed as dealers in such state, unless, pursuant to informal "clearance" with the state officials, the names of non-licensed underwriters may appear therein accompanied by an appropriate "hedge" clause whose purpose is to obviate any possible construction that such advertisement constitutes an offer by

\footnotetext{
${ }^{25}$ If the issuer is, for example, a California corporation, it must ordinarily obtain a permit from the State Corporation Division pursuant to Section 3 of the Corporate Securities Act, CAL. GEN. LAws (Deering, 1931) act 3814 .

30 The states of Arizona, Arkansas, California, Colorado, Louisiana, Mississippi, New Hampshire, New Mexico, Oregon, Rhode Island, South Dakota, Tennessee, Wisconsin and, probably, Michigan.

${ }^{27}$ See the discussion in Smith, supra note 3 , at II 44 .
} 
such non-licensed underwriters. ${ }^{28}$ In any case, the publication of such an advertisement in a newspaper of wide circulation raises certain theoretical problems, even though no violation of the law of the state of publication or primary circulation is involved, arising out of the fact that such newspaper may be circulated in states in which either the issue is not qualified or the underwriters whose names appear therein are not licensed as dealers. ${ }^{29}$

In short, every underwriting involves as a necessary step in the preparation for a public offering an examination of the "Blue Sky" laws of all states proposed to be included in the offering. Action must be taken to qualify the securities and otherwise under such laws to the extent necessary. Local counsel must in some instances be employed to expedite the process of qualification. Practical difficulties may be encountered in effecting qualification on or before the effective date of the federal registration statement. Occasionally, some prohibitory provision of a state statute, or the arbitrary position taken by a state official, or the refusal of the issuer to comply with onerous provisions of a state statute or regulation, may make qualification impossible.

\section{(3) Sanctions Imposed by State Laws}

Practically all the state laws provide for punishment by fine or imprisonment, or both, for violations of their provisions. Many also provide, in effect, either that any contracts made in violation thereof shall be voidable, at the election of the purchaser, or that purchasers of any securities sold in violation thereof shall be entitled to recover the purchase price from any person who participated in such violation. ${ }^{\mathbf{3 0}}$

* Such clearances, of course, give little, if any, legal protection, except in cases where they are based upon an official interpretive regulation of the state commission, adopted pursuant to statutory authority. They should, however, protect from criminal liability where an intent to violate the law is an element of the crime. They are also of practical utility in indicating that proceedings based on such advertisements are not likely to be initiated by the officials who have expressed their approval.

A typical clause of this sort reads as follows:

"This advertisement is not and is under no circumstances to be construed as an offer of these Bonds for sale or as a solicitation of an offer to buy any of such Bonds. The offering is made only by the Prospectus. This advertisement is published on behalf of only those of the undersigned who are registered dealers in securities in this state.

"Copies of the Prospectus may be obtained only from such of the undersigned as are registered dealers in securities in this state."

The language used in the "hedge" clause varies in certain of the states to meet the requirements of the officials of such states. In Colorado and Missouri it is customary to indicate by the use of an asterisk which of the undersigned underwriters are registered as dealers in such states. The Pennsylvania officials are adamant in their view that the names of non-licensed underwriters may not appear in any such advertisement without violation of the Pennsylvania Securities Act.

${ }^{2}$ Such theoretical problems arise, of course, by virtue of the possibility that the circulation of such an advertisement in such states constitutes an "offer" of the securities advertised therein in violation of the laws of such states. The answer may be made that since, as a practical matter, a newspaper is primarily an agency of communication in the state of its publication, advertisers should not be held to account to other states in which, incidentally, such newspaper may be circulated. The problem becomes more acute in connection with advertisements published in magazines of wide national circulation. Attempts have been made to incorporate in such advertisements general "hedge" clauses which seek to establish an immunity for such advertisements from the laws of any state in which either the issue is not qualified or any of the underwriters whose names appear therein are not licensed. It is obvious that such a procedure must be futile, at least so far as issue qualificaton requirements are concerned, since the effect of such a clause is to attempt to deny that the advertisement is in fact an advertisement.

${ }^{30}$ Section 19 of the Indiana Securities Law, Ind. Stat. (Burns, 1933) tit. 25-8rg, for example, provides 
The California Act goes so far as to provide that securities sold in violation of the Act shall be void. ${ }^{31}$

Some courts have construed such remedial provisions as being applicable only where the contract or sale in question was made locally, on the theory that the validity of a contract is determined by the law of the place where the contract was made. $^{32}$ One court, at least, has implied that the contract or sale is voidable irrespective of where it was actually made, provided some act leading up thereto was done in violation of the law providing the remedy. ${ }^{33}$

It might be difficult, of course, as a practical matter, to enforce either the penal or remedial provision of a state law against a nonresident violator, since even the so-called "remedial" provisions might be considered as penal in nature and enforcement thereof refused by the courts of another state on well-recognized principles. Nevertheless, the sanctions are such as to give pause to issuers and underwriters concerned with large offerings involving many states. The situation is such as to suggest that consideration be given to the question whether improvements may not be made, without sacrifice of the public interest, to remove or lighten the burden of compliance with the state laws in the case of securities registered under the Securities Act of 1933 and, accordingly, to reduce the risks incurred in connection with certain innocuous practises, such' as advertising in the manner referred to above.

\section{Correlation of State Laws with the Securities Act of 1933}

\section{(I) Action by Congress to Remove from the States Jurisdiction over Interstate Transactions}

In view of the extensive requirements made by the Securities Act of 1933, issuers and underwriters who are also faced with vexing state requirements may plausibly feel that Congress should take action, under its paramount power, to withdraw from. the states such concurrent jurisdiction as they may now have to legislate concerning interstate transactions. As heretofore noted, that Act (and the Securities Exchange Act of I934) now expressly leave the pre-existing jurisdiction of the states unimpaired. $^{34}$ The result of such action would be to establish an immunity from state laws for transactions in securities of a clearly interstate character. It would not be

as follows: "Every sale or contract for sale made in violation of any of the provisions of this act shall be voidable at the election of the purchaser and the person making such sale or contract for sale and every officer, director or agent of or for such seller who shall have participated or aided in any way in making such sale shall be jointly and severally liable to such purchaser in an action at law in any court of competent jurisdiction upon tender to the seller of the securities sold or of the contract made for the full amount paid by such purchaser. . .."

at Corporate Securities Act, supra note 25, \$16.

${ }^{20}$ See Brocalsa Chemical Co. v. Langsenkamp, 32 F. (2d) 725 (C. C. A. 6th, 1929).

${ }^{3}$ See Bartlett v. Doherty, ro F. Supp. 465 (D. N. H. 1935). In that case an unlicensed agent of a licensed New Hampshire dealer had, the court said, made "sales" in New Hampshire, subject, however, to "confirmation" by the Boston or New York office of the dealer. If these actually were contracts of sale upon a condition subsequent, the case is not, on its facts, inconsistent with Brocalsa Chemical Co, v. Langsenkamp, supra note 32. If, however, the contracts did not come into being until "confirmation," the decision is opposed to that of the Brocalsa Chemical Co. case. In any event, the gist of the court's reasoning is that technical devices should not be available to escape the application of state laws.

" See note 5, supra. 
necessary, in respect of such transactions, either that the securities involved be qualified under the laws of the various states or that the offerors be registered as dealers in securities in such states. Would this involve any sacrifice of public interest? The answer, of course, depends upon the extent to which the public interest is adequately served by the federal law.

It would seem, a priori, that the public interest so far as interstate transactions are concerned, should as a whole be better served by the Securities Act of 1933 than by the heterogeneity of state laws, for otherwise there would have been no reason for federal legislation. The theory is being confirmed by the operation of the Act. The registration and prospectus requirements of the Act make mandatory a much more complete disclosure of essential facts concerning offerings of securities than, in general, do the qualification requirements of the state laws. As a result, the investor now unquestionably has more information at hand on which to base his judgment than was ordinarily available theretofore; moreover, such information is presented to him, as required by the Act, directly in the form of a prospectus conforming to certain established standards, whereas the information furnished under the state laws was usually available only at the state capitol among the public records.: The remedies afforded by the Act to purchasers of securities sold in violation of the provisions of the Act-are considerably more extensive than those similarly afforded by the various state laws. The painstaking thoroughness with which registration statements filed with the Securities and Exchange Commission are customarily prepared, at least in connection with large issues, is persuasive evidence of the effective protection given to the investor by the Securities Act of 1933 in respect of transactions subject to its provisions.

In only two respects may it be asserted that some, at least, of the state laws more adequately serve the public interest than does the Federal Act. To the extent that any of the state laws are based on a different theory than the Federal Act, or cover transactions not covered by the Act, it may, of course, be contended that the Act is not an adequate substitute for state legislation, so far as those states are concerned.

As heretofore noted, the theory of the Securities Act of 1933 is that the proper governmental function in connection with transactions in securities is to prevent fraud by requiring a disclosure to prospective purchasers of all material facts relative to an offering. As also previously noted, some states apparently seek to go further and prevent the sale altogether of certain securities (either on the theory they are unsound, or are per se fraudulent) and the sale of any securities on terms not considered fair, the determination in some cases being made by statute, in others by administrative officials pursuant to statutory authority. Whether the different theory underlying the laws of such states should be regarded as sufficient to justify the retention of state jurisdiction over interstate transactions is a question which may only be resolved by deciding whether the degree of paternalism manifested by such laws is justified either in theory or by its results. Whatever may be the theoretical justification for such a policy, it may be seriously questioned whether, as a practical 
matter, such laws do in fact result in greater protection to the purchaser than is afforded by the Securities Act of 1933 .

That some of the state laws are applicable to a larger number of transactions than is the Securitics Act of 1933 is brought out by a comparison of the exemptions provided under the Federal Act and under the various state laws. For example, Section $3(\mathrm{a})(\mathrm{r})$ of the Act exempts from the registration and prospectus requirements of the Act

"Any security which, prior to or within sixty days after enactment of this title, has been sold or disposed of by the issuer or bona fide offered to the public, but this exemption shall not apply to any new offering of any such security by an issuer or underwriter subsequent to such sixty days."

Again, Section 4(I) of the Act exempts from such requirements

"transactions by any person other than an issuer, underwriter, or dealer; transactions by an issuer not involving any public offering; or transactions by a dealer (including an underwriter no longer acting as an underwriter in respect of the security involved in such transactions), except transactions within one year after the first date upon which the security was bona fide oflered to the public by the issuer or by or through an underwriter (exclud. ing in the computation of such year any time during which a stop order issued under Section 8 is in e'fect as to the security), and except transactions as to securitics constituting the whole or a $I_{\text {ant }}$ of an unsold allotment to or subscription by such dealer as a participant in the distribution of such securities by the issuer or by or through an underwriter."

Most state laws, on the other hand, apply to any offering of non-exempt securities at any time by an issuer or dealer to a member of the public. Such differences in scope likewise involve a question of policy. Even assuming, however, that the coverage of such state laws should be retained in so far as not concurrently provided for under the Federal $\Lambda \mathrm{cl}$, duplicative requirements of state laws might appropriately be eliminated, and this could most easily be accomplished by Congressional action to the effect that, so $\hat{A}_{2} \mathrm{r}$ as transactions comprehended by the Federal Act are concerned, the state laws shiall be inapplicable.

(2) Amendment of the State Laws to Take Cognizance of Registration under Securities Act of 1933

As an alternative, the state laws themselves could be amended either to exempt securities registered under the Securities Act of 1933 or, at least, to make qualification of such securitics possible by some very simple procedure. Amendments of this nature would rliminate onerous duplicative state qualification requirements, but would leave opcrative state dealer-licensing provisions.

While a state which seeks to do more than require a factual disclosure could not reasonably be expected to exempt securities registered under the Federal Act, such state could consistently permit the qualification of securities by the filing of a simple form of application to which could be annexed a copy of the federal prospectus in satisfaction of:informational requirements. The information contained in the prospectus should niormally be sufficient to enable the state administrative body to determine whether the offering is one which is permissible under the state law. 
If, on the other hand, the policy of the state is to prevent fraud through enforced disclosure of material facts concerning offerings, no reason is apparent why such state should not, consistently therewith, take cognizance of the fact that an identical policy underlies the Securities Act of 1933, and either exempt securities registered under the Act or, as a minimum gesture of coöperation, permit qualification under the state law by the simple means suggested above.

Neither proposal involves anything radical or essentially new in principle. Many of the state laws now exempt securities issued under the supervision of public utilities commissions and securities listed on certain recognized stock exchanges. The principle of allowing "credit" for action taken by issuers pursuant to the requirements of recognized public or quasi-public bodies is thus established. It is reasonable to expect that the states should to the same degree rely upon the requirements of, and the standards set by, the Securities and Exchange Commission. It may be noted that one state, at least, has taken a step in this direction. The new South Carolina Act, effective October 28, I936, permits securities of "seasoned" corporations registered with the Securities and Exchange Commission (on Form A-2) to be qualified by means of a simple process of "notification."35

One further feature should be incorporated in any such amendment of a state law, based on a recognition of the practice obtaining under the Securities Act of 1933 . Registration statements under the Act do not become "effective" until the twentieth day after their filing. This twenty day period is designed to be a period during which prospective purchasers may be acquainted with the facts concerning the securities without being subjected to selling pressure and without, in fact, any offering being made. It is important, therefore, that it should be possible to distribute information concerning securities preliminarily without having such distribution constitute an offer under the state laws; it is important, moreover, that it should be possible to make an offering in the various states immediately upon the federal registration statement's becoming effective. Both objectives may be accomplished if amendments of state laws, along the lines suggested above, permitting the qualification of securities by the filing of a simple form of application together with a copy of the federal prospectus, also permit such qualification to become effective by the use of a preliminary and tentative form of the prospectus, subject, however, to the filing of a definitive prospectus upon or as soon as possible after the effective date of the federal registration statement.

Other suggestions may be made for improving the state laws, in the interest of uniformity and practicable workability. These are, however, beyond the scope of the present discussion, since they are unrelated to the Federal Acts. It is enough at present to have indicated briefly some of the problems arising under the state laws and to have suggested some means of removing doubts which now exist as to the applicability of the state laws to certain transactions, and of lightening the burden of compliance with such laws, in connection with transactions already subjected to regulation under the Securities Act of 1933 .

${ }^{85}$ S. C. Laws 1936, H. B. $1807, \$ 7(2)$. 